TITLE:

\title{
Reproductive success of two male morphs in a free-ranging population of Bornean orangutans
}

\section{AUTHOR(S):}

Tajima, Tomoyuki; Malim, Titol P.; Inoue, Eiji

\section{CITATION:}

Tajima, Tomoyuki ...[et al]. Reproductive success of two male morphs in a free-ranging population of Bornean orangutans. Primates 2018, 59: 127-133

\section{ISSUE DATE:}

\section{8}

URL:

http://hdl.handle.net/2433/259300

\section{RIGHT:}

This is a post-peer-review, pre-copyedit version of an article published in Primates. The final authenticated version is available online at: http://dx.doi.org/10.1007/s10329-017-0648-1.; This is not the published version. Please cite only the published version.; この論文は出版社版でありません。引用の際には出版社版をご確認ご利用ください。 
1 Original Article

2

3 Reproductive success of two male morphs in a free-ranging population of Bornean

4 orangutans

5

6 Tomoyuki Tajima ${ }^{1}$, Titol P. Malim ${ }^{2}$ and Eiji Inoue ${ }^{3}$

7

8 ' ${ }^{1}$ Laboratory of Human Evolution Studies, Graduate School of Science, Kyoto University,

9 Kyoto, Japan; ${ }^{2}$ Sabah Wildlife Department, Kota Kinabalu, Sabah, Malaysia;

$10{ }^{3}$ Department of Biology, Faculty of Science, Toho University, Chiba, Japan

11

12 Correspondence to: Tajima, T. Laboratory of Human Evolution Studies, Graduate School

13 of Science, Kyoto University, Kitashirakawa Oiwake, Sakyo, Kyoto 6068502 Japan.

14

15 Phone: $+81-75-753-4085$

16 Fax: $+81-75-753-4115$

17 E-mail: tajima002@gmail.com 
19 The original version is available at

20 www.springer.com $<$ https://ink.springer.com/article/10.1007/s10329-017-0648-1>

21 SharedIt $<$ https://t.co/xF15ycBued $>$

\section{Acknowledgements}

24 We are grateful to Sabah Biodiversity Centre, Sabah Wildlife Department, and Economic

25 Planning Unit of Malaysia Federal Government for permitting this study. We are also

26 grateful to Dr. Noko Kuze, Dr. Henry Bernard, Dr. Vijay Kumar, Ms. Sylvia Alsisto, Mr.

27 Sailun Aris, and all the staff of the Sepilok Orangutan Rehabilitation Centre for their kind

28 support of our research activity in Sabah, Malaysia, and to Dr. Naofumi Nakagawa for

29 helpful comments on our manuscript. The present study was supported by Grants-in-Aid

30 for Japan Society for the Promotion of Science (JSPS) Research Fellow (Grant no.

31 10J01218 to Tomoyuki Tajima); JSPS Core-to-Core Program, Advanced Research

32 Networks "Tropical Biodiversity Conservation" Wildlife Research Center, Kyoto

33 University, Japan, and by the Ministry of Education, Culture, Sports, Science and

34 Technology (MEXT), Leading Graduate School Program in Primatology and Wildlife

35 Science, Kyoto University, Japan. We obtained appropriate permission from the Sabah

36 Wildlife Department and Sabah Biodiversity Council before conducting our research, and 
37 the study complies with current Malaysian laws, as well as with the "Guidelines for Care

38 and Use of Nonhuman Primates" and "Guideline for field research of non-human

39 primates" provided by the Primate Research Institute of Kyoto University, Japan.

40

41

42

43

44

45

46

47 Abstract

48 The reproductive success of male primates is not always associated with dominance status.

49 For example, even though male orangutans exhibit intra-sexual dimorphism and clear

50 dominance relationships exist among males, previous studies have reported that both

51 morphs are able to sire offspring. The present study aimed to compare the reproductive

52 success of two male morphs, and to determine whether unflanged males sired offspring

53 in a free-ranging population of Bornean orangutans, using 12 microsatellite loci to

54 determine the paternity of eight infants. A single flanged male sired most of the offspring 
55 from parous females, and an unflanged male sired a firstborn. This is consistent with our

56 observation that the dominant flanged male showed little interest in nulliparous females,

57 whereas the unflanged males frequently mated with them. This suggests that the dominant

58 flanged male monopolizes the fertilization of parous females and that unflanged males

59 take advantage of any mating opportunities that arise in the absence of the flanged male,

60 even though the conception probability of nulliparous females is relatively low.

61

62 Keywords: paternity analysis; male dominance; bimaturism; Bornean orangutan; Pongo

63 pygmaeus; free-ranging population 


\section{$64 \quad$ Introduction}

65

66

67
In most mammals, males compete to fertilize reproductive females (Trivers 1972), and previous studies of social primates suggest that dominant males usually have more access to fertile females and sire more offspring than subordinate males (Altmann 1962; Cowlishaw and Dunbar 1991; Kutsukake and Nunn 2006). However, genetic analyses have revealed that the most dominant male is not always the most successful sire (Ellis 1995; Majolo et al. 2012) and dominant males' monopolization of fertilization can be reduced by female estrus synchrony, the number of rival males (Kutsukake and Nunn 2006; Ostner et al. 2008), and the alternative reproductive tactics of subordinate males (Setchell 2008).

Unlike other great apes, wild orangutans lead a semi-solitary lifestyle (Delgado and van Schaik 2000). Orangutans are characterized by male bimaturism, a phenomenon in which sexually mature males exhibit intra-sexual dimorphism and that might have evolved as a result of intense male-male competition (Utami Atmoko et al. 2009a). In this system, the dominant morphs, which are called "flanged males" (FLMs), have large bodies and fully developed secondary sexual characteristics, including prominent cheek pads, long fur, and a throat sack, whereas the subordinate morphs, which are called "unflanged males" (UFMs), have skeletally mature female-sized bodies and lack 
82 secondary sexual characteristics (Delgado and van Schaik 2000). In addition to their

83 contrasting morphology, the two male morphs also exhibit different social behavior

84 (Utami Atmoko et al. 2009a). For example, FLMs are highly competitive, as evidenced

85 by wounds on their faces and bodies (Utami Atmoko et al. 2009a), whereas UFMs are

86 usually more tolerant, thereby obscuring the dominance relationships among UFMs

87 (Utami Atmoko et al. 2009a).

Previous studies have also reported that the dominant and subordinate orangutan

morphs also differ in their mating behavior. For example, FLMs primarily copulate during

90 their consortship with females (Galdikas 1985a; Mitani 1985), whereas UFMs often

91 perform forced copulations (Galdikas 1985b; Mitani 1985) and often do so in the absence

92 of FLMs (Utami Atmoko et al. 2009b). These observations suggest that FLMs sire more

93 offspring than UFMs. However, it has been reported that both male morphs can sire

94 offspring (Utami et al. 2002; Goossens et al. 2006), and paternity studies have reported

95 that almost half of Sumatran orangutan offspring are sired by UFMs, whereas most

96 Bornean orangutan offspring are sired by FLMs (Utami Atmoko et al. 2009b). Banes et

97 al. (2015), who sampled a mixed population of wild-born and ex-captive Bornean

98 orangutans, also reported that a dominant FLM sired most of the population's offspring.

99 However, orangutan paternity studies have been based on molecular genetic 
100 analyses and have generally lacked behavioral observation. In addition, Utami Atmoko et

101 al. (2009b) pointed out that UFMs sire most firstborn offspring in Sumatra. Yet, this has

102 never been investigated in Bornean orangutans, and the paternity studies that have been

103 conducted in Borneo (e.g., Goossens et al. 2006; Banes et al. 2015) provide no

104 information regarding female parity or offspring birth order.

106 dominant and subordinate male morphs in Borneo, and to determine whether the firstborn

107 offspring of female Bornean orangutans are sired by UFMs. The present study focused

108 on a free-ranging population that was primarily composed of rehabilitated orangutans in

109 Kabili Sepilok Forest Reserve, because the females of the population have been regularly

110 monitored and their parity has been documented. To complement the paternity analyses,

111 the behavior of the males was also observed.

113 Methods

114 Study Site

115 Sample collection and behavioral observation were conducted by the author TT

116 with the help of local assistants in the Kabili Sepilok Forest Reserve (KSFR), which

117 comprises $\sim 4200$ ha of lowland dipterocarp forest and harbors $\sim 200$ orangutans 
118 (Ancrenaz et al. 2005). The Sepilok Orangutan Rehabilitation Centre (SORC; $05^{\circ} 51.841^{\prime}$

$119 \mathrm{~N}, 117^{\circ} 57.003^{\prime} \mathrm{E}$ ), which was established in 1964, is located adjacent to KSFR and has

120 managed a rehabilitation project in which orphaned Bornean orangutans (P. pygmaeus

121 morio) are rescued from the state of Sabah, Malaysia and then released into the reserve

122 (Kuze et al. 2008). The SORC has established feeding platforms (Fig. 1), which the

123 rehabilitated orangutans visit voluntarily, and supplies the orangutans with supplemental

124 food (mainly bananas and sugarcane) twice a day (10:00 and 15:00 h).

126 Animals

The present study monitored eight adult orangutans (one FLM, three UFM, and

128 four parous females) between December 2010 and August 2012. The age-sex class of the

129 individuals was determined based on morphology (Wich et al. 2004; Kuze et al. 2005).

130 Reliable information about the rehabilitated orangutans was obtained from the SORC

131 studbook (Table 1). One of the UFMs (MK) and two of the parous females (MM and BR)

132 were rehabilitated, and the other two parous females (MR and CL) were descendants of

$133 \mathrm{MM}$ and $\mathrm{BR}$. The origin of the other three adult males $(\mathrm{CD}, \mathrm{RG}$, and $\mathrm{TK})$ is unknown.

134 One of the population's UFMs (MK) and one adult female (BR), along with her offspring,

135 were translocated to another reserve in 2012. 
137 (245 d; Graham 1988) and each offspring's birth date, following Knott et al. (2010).

138 Reproductive females were defined as those that lacked dependent infants and that failed

139 to exhibit labial swelling, which only occurs during pregnancy (Delgado and van Schaik,

140 2000). During our study, the adult males were also observed to mate with nulliparous

141 females (6-10 years old), some of which were potentially fertile, since the age at first

142 parturition in the SORC is $8-15$ years (Kuze et al. 2008).

144 [insert Fig. 1 around here]

145 [insert Table 1 around here]

147 Sample and Data Collection

149 during July-August 2010, December 2010-April 2011, and July 2011-August 2012.

150 These periods encompassed three conceptions (MM3, CL3, and MO). Whenever possible,

151 we followed the same animal from the morning to the night nest for a maximum of three

152 consecutive days, in order to record sexual and agonistic interactions with other

153 individuals. The behavior of the individuals was observed for a total of $1557 \mathrm{~h}$ (males: 
154438 h; females: 1045 h). During these observations, copulation was recorded when penile

155 intromission was observed.

156

157 Genotyping and Paternity Analyses

158 We analyzed the paternity of 22 individuals, but we failed to collect DNA

159 samples from four nulliparous females (TP, RSL, SG, and OT). From 2010 to 2014,

160 seventy-three fresh fecal samples were collected from 19 individuals, which included

161 eight mother-infant units (Table S1). However, three infants (CL3, MM3, and MO) had

162 died before the non-invasive samples were taken. Therefore, we collected muscle and

163 liver tissues from the postmortem specimens, with appropriate permissions from the

164 SORC and Sabah Wildlife Department. Four adult males were genotyped as paternal

165 candidates, although we were unable to collect samples from an FLM that had been

166 occasionally observed in 2009. Following Wich et al. (2004), we estimated that the five

167 young males were less than 14 years old at the time of each conception and, thereby,

168 regarded them as adolescent and excluded them from the paternal analysis. To obtain

169 DNA through non-invasive means, we swabbed the surface of feces from the individuals

170 and then soaked the swabs in tubes that contained lysis buffer (Longmire et al. 1997). The

171 DNA of fecal and post-mortem tissue samples was then extracted using the QIAamp DNA 
172 Stool Mini Kit (Qiagen, Valencia, California, USA) and DNeasy Blood \& Tissue Kit

173 (Qiagen), respectively. Multiplex polymerase chain reaction (PCR) was performed as

174 described in Inoue et al. (2007), using the QIAGEN multiplex PCR Kit (Qiagen). We then

175 amplified 12 microsatellite loci (Goossens et al. 2006) from each of the DNA samples

176 using two multiplex primer sets: multil (D2s1326, D3s2459, D5s1457, D12s375,

177 D16s420, and D1s2130) and multi2 (D1s550, D4s1627, D5s1505, D6s501, D2s141, and

$178 D 13 s 765)$. Because the non-invasive samples had low DNA contents, we needing to

179 account for the low rate of DNA amplification and the resulting genotyping errors (Lampa

180 et al. 2013). For accurate genotyping, homozygous and heterozygous alleles were scored

181 after amplification in three and two independent PCRs, respectively (Lampa et al. 2013).

182 Genotypes for all 12 microsatellite loci were obtained for 22 individuals (Table S1). We estimated the paternity of the offspring using CERVUS 3.0 (Kalinowski et al. 2007), with 10,000 simulations and confidence levels of $95 \%$ (relaxed) and $99 \%$ (strict).

186 Results

187

Paternity 
190 period (Table 2). No mismatches were observed between the offspring and expected sires

191 at any locus. One FLM (CD) sired five non-firstborn offspring, whereas a UFM (RG)

192 sired a firstborn offspring (SP). Another firstborn (RN) was sired by CD, who has been

193 an FLM since 2010; no information regarding its morph and status in 2004 is available.

194 We could not determine the paternity of two offspring ( $\mathrm{SL}$ and $\mathrm{CH}$ ) that were born in June

1952010 , and we failed to collect DNA samples from an FLM that was occasionally observed

196 at the feeding platforms around the estimated timing of these two conceptions (i.e.,

197 October 2009).

198

199 [insert Table 2 around here]

Male agonistic interaction

We observed 22 cases of agonistic interactions among the four adult males. All

203 of these interactions occurred in the presence of females, and male dominance relations

204 were established on the basis of these dyadic interactions (Table 3). The FLM (CD) was

205 always dominant over the UFMs, and linear dominance was observed among the UFMs.

206 The FLM only exhibited aggression in the presence of reproductive parous females,

207 whereas the UFMs competed for access to both reproductive parous and nulliparous 
208 females (Table 4).

209

210 [insert Table 3 around here]

211 [insert Table 4 around here]

212

213

Mating interaction

214

Forty-four copulations were documented during the study period (37 and seven

215 in the male-and female-focal observations, respectively). The FLM copulated with parous

216 females in two cases, and the UFMs also copulated with parous females in 21 cases,

217 always in the absence of the FLM. However, the FLM was not observed to make any

218 attempts to copulate with or inspect the genitals of nulliparous females, whereas the

219 UFMs were observed to copulate with the nulliparous females in 21 cases, and all of the

220 UFMs were observed to copulate with both reproductive parous and nulliparous females

221 (Table 5). We also observed 136 cases of males inspecting female genitals, either by hand

222 or mouth, and subsequent copulation occurred in $34(25.0 \%)$ of these cases. The UFMs

223 inspected nine nulliparous females and copulated with four of them, only one of which

224 (AN) become pregnant during the study period. 
226 [insert Table 5 around here]

227

228 Discussion

229

The purpose of the present study was to compare the reproductive success of

230 Bornean FLMs and UFMs, and determine whether UFMs sired firstborn offspring. The

231 paternity results of the present study are basically consistent with those of previous

232 paternity studies in Borneo (Table 6) and suggest that dominant FLMs might be able to

233 monopolize the fertilization of females within certain areas (Goossens et al. 2006; Banes

234 et al. 2015). Even though it is possible that the rehabilitation project influenced the

235 reproduction of the animals through interactions with the human staff and with other

236 rehabilitant orangutans, our paternity results are not different from those of previous

237 studies. Our observations that all UFMs copulated with parous females when the FLM

238 was absent and that only the UFMs mated with nulliparous females are also consistent

239 with the observations of previous behavioral studies (Mitani 1985; Galdikas 1985a, b;

240 Utami Atmoko et al. 2009b), which again suggests the rehabilitation project at the SORC

241 has little impact on the mating interactions or offspring paternity of the studied orangutans.

243 of the offspring born to parous females, even though we observed copulation between the 
244 two. A previous hormone study suggested that female Bornean orangutans might copulate

245 with the most dominant male near the time of ovulation, thereby resulting in more

246 conceptions when mating with the FLM (Knott et al. 2010). We observed that males at

247 SORC performed frequent genital inspection, which might help to estimate the

248 reproductive state of females (Knott et al. 2010). Furthermore, orangutan sperm cells have

249 better-developed acrosomes than either chimpanzee or gorilla sperm cells, which

250 facilitates conception (Fujii-Hanamoto et al. 2011). These studies may explain why the

251 dominant FLM had the highest reproductive success and the UFMs did not.

252

253 [insert Table 6 around here]

254

The present study also provides new evidence for the siring of firstborn offspring

256 (e.g., SP) by UFMs, as previously reported from Sumatra (Utami Atmoko et al. 2009b).

257 Several researchers have reported that FLMs show little interest in nulliparous females

258 (Schürmann 1981; Galdikas 1985a). Indeed, in the present study, the FLM did not attempt

259 to either copulate with or inspect the genitals of any nulliparous female, whereas all of

260 the UFMs copulated with nulliparous females, and some of them competed with one

261 another for access in front of nulliparous females. In orangutans, nulliparous females are 
262 regarded as less fertile than parous females, owing to adolescent sterility (Galdikas 1995;

263 Knott and Kahlenberg 2007), so the FLMs might focus their efforts on mating with parous

264 females, whereas UFMs mate with all potentially reproductive females, including

265 nulliparous ones (Utami Atmoko et al. 2009b). The latter conclusion is also supported by

266 our observations that only the UFMs exhibited agonistic interactions in proximity to

267 nulliparous females.

The tendency of subordinate males to mate with nulliparous females has also

269 been reported in other African great apes. In eastern chimpanzees (Pan troglodytes

270 schweinfurthii), for example, high-ranking males prefer to mate with older parous females

271 (Muller et al. 2006), whereas low-ranking adult and adolescent males copulate more with

272 nulliparous females (Watts 2015), which are regarded as less desirable mates

273 (Wroblewski et al. 2009). In the multi-male groups of mountain gorilla (Gorilla beringei

274 beringei), the most dominant males copulate more with parous females, whereas the

275 subordinate males copulate more with nulliparous females (6-8 years old; Stoinski et al.

276 2009), which subsequently bear offspring (Nsubuga et al. 2008). Therefore, mating with

277 nulliparous females is probably an alternative reproductive tactic. 
280 previous studies (e.g., Utami Atmoko et al. 2009a). It is possible that long-term

281 interactions between ex-rehabilitants might influence the relationships among UFMs.

282 However, owing to our study's small sample size, we were unable to determine whether

283 dominance rank affected the siring of firstborn offspring. Therefore, future studies should

284 focus on the dominance relationships of UFMs, as well as the possible effects of such

285 relationships on reproductive success.

286

287 References

288 Alberts SC, Altmann J, Wilson ML (1996) Mate guarding constrains foraging activity of male baboons. Anim Behav 51: 1269-1277Altmann S (1962) A field study of the sociobiology of rhesus monkeys, Macaca mulatta. Ann NY Acad Sci 102: 338-435

Ancrenaz M, Gimenez O, Ambu L (2005) Aerial surveys give new estimates for orangutans in Sabah, Malaysia. PLoS Biol 3: e3

293 Banes GL, Galdikas BM, Vigilant L (2015) Male orang-utan bimaturism and reproductive success at Camp Leakey in Tanjung Puting National Park, Indonesia. Behav Ecol Sociobiol 69: 1785-1794

296 Bates D, Mächler M, Bolker B, Walker S (2015) Fitting linear mixed-effects models using lme4. J Stat Softw 67: 1-48 
298 Bercovitch F (1983) Time budgets and consortships in olive baboons (Papio anubis).

300 Cowlishaw G, Dunbar RIM (1991) Dominance rank and mating success in male primates.

Delgado RA, van Schaik CP (2000) The behavioral ecology and conservation of the orangutan (Pongo pygmaeus): a tale of two islands. Evol Anthr 9: 201-218

Dunkel L, Arora N, van Noordwijk MA, Utami Atmoko SS, Putra AP, Krützen M, van Schaik CP (2013) Variation in developmental arrest among male orangutans: a comparison between a Sumatran and a Bornean population. Front Zool 10: 12

307 Ellis L (1995) Dominance and reproductive success among nonhuman animals: a crossspecies comparison. Ethol Sociobiol 16: 257-333

Fox EA (2002) Female tactics to reduce sexual harassment in the Sumatran orangutan

311 Fujii-Hanamoto H, Matsubayashi K, Nakano M, Kusunoki H, Enomoto T (2011) A comparative study on testicular microstructure and relative sperm production in gorillas, chimpanzees, and orangutans. Ame J primatol 73: 570-577

314 Galdikas BM (1981) Orangutan reproduction in the wild. In: Graham CE (ed) The reproductive biology of the great apes, Academic Press, New York, pp 281-300 
316 Galdikas BM (1985a) Adult male sociality and reproductive tactics among orangutans at

317 Tanjung Puting. Folia Primatol 45: 9-24

318 Galdikas BM (1985b) Subadult male orangutan sociality and reproductive behavior at

319 Tanjung Puting. Am J Primatol 8: 87-99

320 Galdikas BM (1995) Social and reproductive behavior of wild adolescent female orangutans. In: Nadler RD, Galdikas BMF, Sheeran LK, Rosen N (eds) The neglected ape, Springer, Boston, pp 163-182

323 Goossens B, Setchell JM, James SS, Funk SM, Chikhi L, Abulani A, Ancrenaz M, Ancrenaz-Lackman I, Bruford MW (2006) Philopatry and reproductive success in Bornean orang-utans (Pongo pygmaeus). Mol Ecol 15: 2577-2588

Goossens B, Chikhi L, Jalil MF, James S, Ancrenaz M, Ancrenaz-Lackman I, Bruford, MW (2009) Taxonomy, geographic variation and population genetics of Bornean and Sumatran orangutans. In: Wich SA, Utami Atmoko SS, Mitra Setia T, van Schaik CP (eds) Orangutans: Geographic variation in behavioral ecology and conservation. Oxford University Press, New York, pp 1-14

331 Graham C (1988) Reproductive physiology. In: Schwartz JH (ed) Orang-utan biology. Oxford University Press, Oxford, pp 91-103

333 Inoue E, Inoue-Murayama M, Takenaka O, Nishida T (2007) Wild chimpanzee infant 
urine and saliva sampled noninvasively usable for DNA analyses. Primates 48:156-

Kalinowski ST, Taper ML, Marshall TC (2007) Revising how the computer program CERVUS accommodates genotyping error increases success in paternity assignment. Mol Ecol 16:1099-106

Knott CD, Kahlenberg SM (2007) Orangutans in perspective: forced copulations and female mating resistance. In: MacKinnon KC, Panger M, Bearder SK (eds) Primates in perspective, Oxford University Press, New York, pp 290-305

Knott CD, Emery Thompson M, Stumpf RM, McIntyre MH (2010) Female reproductive strategies in orangutans, evidence for female choice and counterstrategies to infanticide in a species with frequent sexual coercion. Proc Biol Sci 277: 105-13

Kutsukake N, Nunn CL (2006) Comparative tests of reproductive skew in male primates: the roles of demographic factors and incomplete control. Behavioral Ecology and Sociobiology. 60: 695-706

Kuze N, Malim TP, Kohshima S (2005) Developmental changes in the facial morphology of the Borneo orangutan (Pongo pygmaeus): possible signals in visual communication. Am J Primatol 65:353-76 
353 Kuze N, Sipangkui S, Malim TP (2008) Reproductive parameters over a 37-year period of free-ranging female Borneo orangutans at Sepilok Orangutan Rehabilitation Centre. Primates 49:126-34

Lampa S, Henle K, Klenke R, Hoehn M, Gruber B (2013) How to overcome genotyping errors in non-invasive genetic mark-recapture population size estimation-A review of available methods illustrated by a case study. The Journal of Wildlife Management 77: $1490-1511$

Longmire JL, Maltbie M, Baker RJ (1997) Use of" lysis buffer" in DNA isolation and its implication for museum collections. Museum of Texas Tech University.

Majolo B, Lehmann J, de Bortoli Vizioli A, Schino G (2012) Fitness-related benefits of dominance in primates. Am J Phys Anthropol 147:652-60

Matsubara M (2003) Costs of mate guarding and opportunistic mating among wild male Japanese macaques. Int J Primatol 24: 1057-1075

Mitani J (1985) Mating behaviour of male orangutans in the Kutai Game Reserve, Indonesia. Anim Behav 33: 392-402 
370 Nsubuga AM, Robbins MM, Boesch C, Vigilant L (2008) Patterns of paternity and group

371 fission in wild multimale mountain gorilla groups. Am J Phys Anthropol 135: 263-

373 Ostner J, Nunn C, Schülke O (2008) Female reproductive synchrony predicts skewed paternity across primates. Behav Ecol 19: 1150-1158

Pradhan G, van Noordwijk M, van Schaik C (2012) A model for the evolution of developmental arrest in male orangutans. Am J Phys Anthropol 149: 18-25

R Core Team (2016) R: A language and environment for statistical computing. R Foundation for Statistical Computing, Vienna, Austria. URL https://www.Rproject.org/.

Radespiel U, Dal Secco V, Drögemüller C, Braune P, Labes E, Zimmermann E (2002) Sexual selection, multiple mating and paternity in grey mouse lemurs, Microcebus murinus. Animal Behaviour 63: 259-268

Schürmann, CL (1981) Courtship and mating behavior of wild orangutans in Sumatra. In: Chiarelli AB, Corruccini R (eds) Primate behavior and sociobiology. Springer, Berlin Heidelberg, pp 130-135 
Stoinski TS, Rosenbaum S, Ngaboyamahina T, Vecellio V, Ndagijimana F, Fawcett K (2009) Patterns of male reproductive behaviour in multi-male groups of mountain gorillas: examining theories of reproductive skew. Behaviour 146:1193-1215

Trivers R (1972) Parental investment and sexual selection. Sexual Selection \& the Descent of Man, Aldine de Gruyter, New York, 136-179.

Utami SS, Goossens B, Bruford MW, de Ruiter JR, van Hooff JA (2002) Male bimaturism and reproductive success in Sumatran orang-utans. Behav Ecol 13: 643-652

Utami Atmoko SS, Singleton I, van Noordwijk MA, van Schaik CP, Mitra Setia T (2009a) Male-male relationships in orangutans. In: Wich SA, Utami Atmoko SS, Mitra Setia T, van Schaik CP (eds) Orangutans: geographic variation in behavioral ecology and conservation. Oxford University Press, New York, pp 225-234 van Noordwijk MA (2009b) Orangutan mating behavior and strategies. In: Wich SA, Utami Atmoko SS, Mitra Setia T, van Schaik CP (eds) Orangutans: Geographic Variation in Behavioral Ecology and Conservation. Oxford University Press, New York, pp 235-244 
407 Watts DP (2015) Mating behavior of adolescent male chimpanzees (Pan troglodytes) at

408 Ngogo, Kibale National Park, Uganda. Primates 56: 163-172

409 Wich SA, Utami-Atmoko SS, Mitra Setia T, Rijksen HD, Schürmann C, van Hooff 410 JARAM, van Schaik CP (2004) Life history of wild Sumatran orangutans (Pongo

411 abelii). J Hum Evol 47: 385-398

412 Wroblewski EE, Murray CM, Keele BF, Schumacher-Stankey JC, Hahn BH, Pusey AE

413 (2009) Male dominance rank and reproductive success in chimpanzees, Pan

414 troglodytes schweinfurthii. Animal Behaviour 77: 873-885

415

416

417

418

419

420

421

422

423

424 
a

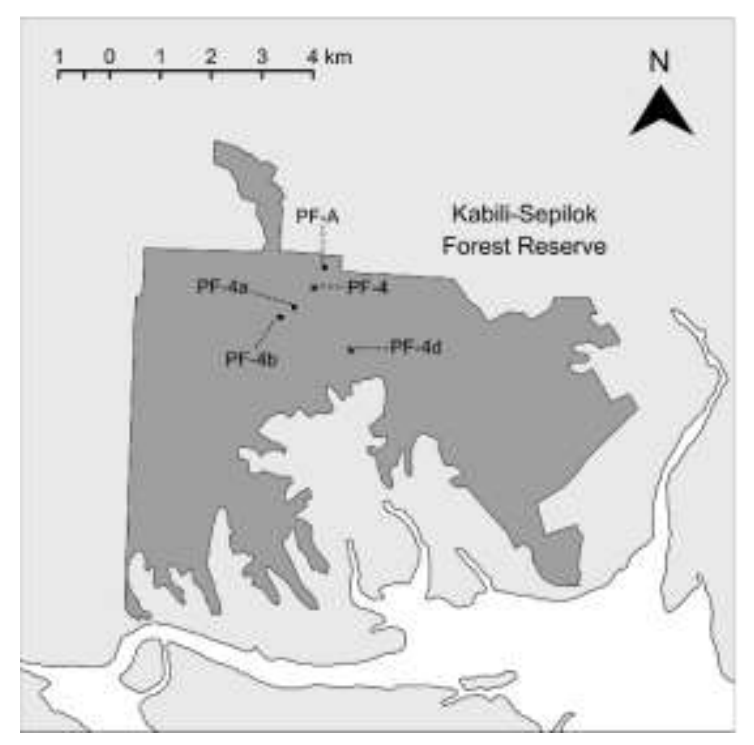

b

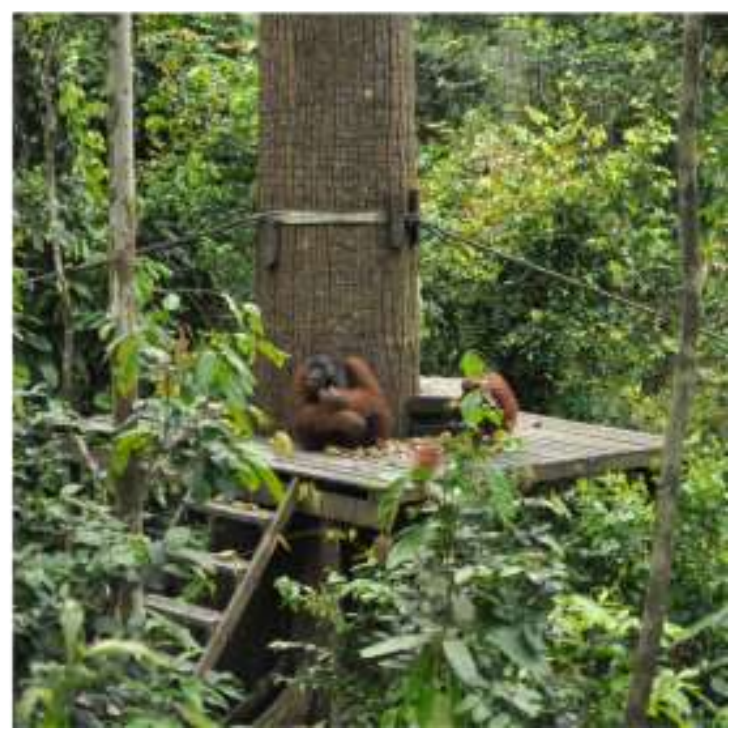

426

427

Fig. 1 Kabili Sepilok Forest Reserve. (a) Location, (b) Feeding platform in the reserve

428

429

430

431

432

433

434

435

436

437

438

439

440

441

442

443

444

445

446

447

448 
Table 1 Information of subject individuals $(\mathrm{N}=26)$

\begin{tabular}{|c|c|c|c|c|c|c|c|c|}
\hline Category & $\begin{array}{l}\text { Studbook } \\
\text { ID }\end{array}$ & $\begin{array}{l}\text { Name } \\
\text { ID }\end{array}$ & Sex & $\begin{array}{l}\text { Year of } \\
\text { age }^{\mathrm{a}}\end{array}$ & Date of birth ${ }^{b}$ & Origin $^{c}$ & $\begin{array}{l}\text { Focal } \\
\text { hour }\end{array}$ & $\begin{array}{l}\text { DNA } \\
\text { analyzed }\end{array}$ \\
\hline FLM & - & $\mathrm{CD}$ & $\mathrm{M}$ & $21^{\mathrm{a}}$ & - & Unknown, identified in 2010 & 43 & Yes \\
\hline \multirow[t]{3}{*}{ UFM } & PP412 & MK & $\mathrm{M}$ & 18 & 18-Dec-1994 & Rehabilitated & 150 & Yes \\
\hline & - & RG & $\mathrm{M}$ & $15^{\mathrm{a}}$ & - & Unknown, identified in 2007 & 204 & Yes \\
\hline & - & TK & M & $15^{\mathrm{a}}$ & - & Unknown, identified in 2010 & 41 & Yes \\
\hline \multirow[t]{4}{*}{ Parous } & PP249 & MR & $\mathrm{F}$ & 22 & 03-Feb-1990 & Offspring of rehabilitated mother & 265 & Yes \\
\hline & PP505 & $\mathrm{MM}$ & $\mathrm{F}$ & 18 & 28-Nov-1996 & Wild-born, rehabilitated & 329 & Yes \\
\hline & PP483 & $\mathrm{CL}$ & $\mathrm{F}$ & 14 & 19-Sep-1996 & Offspring of rehabilitated mother & 300 & Yes \\
\hline & PP617 & $\mathrm{BR}$ & $\mathrm{F}$ & 12 & 27-Nov-1999 & Wild-born, rehabilitated & 151 & Yes \\
\hline \multirow[t]{8}{*}{ Offspring } & PP688 & $\mathrm{RN}$ & M & 6 & 07-Oct-2004 & Firstborn offspring of MM & - & Yes \\
\hline & PP739 & SL & $\mathrm{F}$ & 0 & 01-Jun-2010 & Offspring of MR & - & Yes \\
\hline & PP740 & $\mathrm{CH}$ & $\mathrm{M}$ & 0 & 10-Jun-2010 & Offspring of BR & - & Yes \\
\hline & PP748 & MM3 & $\mathrm{F}$ & - & 04-Dec-2011 & Offspring of MM & - & Yes \\
\hline & PP749 & CL3 & $\mathrm{F}$ & - & 13-Mar-2012 & Offspring of CL & - & Yes \\
\hline & PP753 & MO & M & - & 13-Jan-2013 & Offspring of MR & - & Yes \\
\hline & PP756 & AW & $\mathrm{M}$ & - & 27-Jul-2013 & Offspring of CL & - & Yes \\
\hline & PP758 & $\mathrm{SP}$ & M & - & 20-Feb-2014 & Offspring of AN & - & Yes \\
\hline \multirow[t]{10}{*}{ Nulliparous } & PP655 & $\mathrm{TP}$ & $\mathrm{F}$ & 10 & 24-Маy-2002 & Wild-born, rehabilitated & - & - \\
\hline & PP660 & RS & $\mathrm{F}$ & 9 & 27-Nov-2002 & Wild-born, rehabilitated & - & Yes \\
\hline & PP658 & HP & $\mathrm{F}$ & 9 & 30-Aug-2002 & Wild-born, rehabilitated & - & Yes \\
\hline & PP665 & AN & $\mathrm{F}$ & 8 & 25-Jan-2003 & Wild-born, rehabilitated & - & Yes \\
\hline & PP725 & OT & $\mathrm{F}$ & 8 & 16-Oct-2007 & Wild-born, rehabilitated & - & - \\
\hline & PP663 & RSL & $\mathrm{F}$ & 7 & 15-Dec-2002 & Offspring of rehabilitated mother & - & - \\
\hline & PP677 & $\mathrm{CT}$ & $\mathrm{F}$ & 7 & 16-Dec-2003 & Wild-born, rehabilitated & - & Yes \\
\hline & PP691 & $\mathrm{KR}$ & $\mathrm{F}$ & 7 & 28-Feb-2005 & Wild-born, rehabilitated & - & Yes \\
\hline & PP719 & GN & $\mathrm{F}$ & 7 & 08-May-2007 & Wild-born, rehabilitated & - & Yes \\
\hline & PP689 & SG & $\mathrm{F}$ & 6 & 23-Jan-2005 & Wild-born, rehabilitated & - & - \\
\hline
\end{tabular}


Table 2 Results of paternity assignment at 12 microsatellite loci $(\mathrm{N}=8)$

\begin{tabular}{|c|c|c|c|c|c|c|c|c|c|}
\hline \multirow{2}{*}{ Offspring } & \multirow{2}{*}{ Date of birth } & \multirow{2}{*}{ Birth order } & \multirow{2}{*}{ Mother } & \multirow{2}{*}{ Father } & \multirow{2}{*}{ Morph } & \multirow{2}{*}{$\begin{array}{c}\text { Number of } \\
\text { mismatches } \\
\text { with the next } \\
\text { best male }\end{array}$} & \multirow{2}{*}{$\begin{array}{c}\text { Level of } \\
\text { confidence } \\
(\%)\end{array}$} & \multicolumn{2}{|c|}{$\begin{array}{c}\text { Number of paternal candidates } \\
\text { (Number of sampled males) }\end{array}$} \\
\hline & & & & & & & & FLM & UFM \\
\hline $\mathrm{RN}$ & 07-Oct-04 & $1 \mathrm{st}$ & MM & $\mathrm{CD}$ & unknown & 4 & 99 & $1(0)^{\mathrm{a}}$ & $2(0)^{\mathrm{b}}$ \\
\hline SL & 01-Jun-10 & $3 \mathrm{rd}$ & MR & - & unknown & 3 & - & $1(0)^{b}$ & $2(2)$ \\
\hline $\mathrm{CH}$ & 10-Jun-10 & 2 nd & $\mathrm{BR}$ & - & unknown & 2 & - & $1(0)^{b}$ & $2(2)$ \\
\hline MM3 & 04-Dec-11 & $3 \mathrm{rd}$ & $\mathrm{MM}$ & $\mathrm{CD}$ & FLM & 3 & 99 & $1(1)$ & $3(3)$ \\
\hline CL3 & 13-Mar-12 & $3 \mathrm{rd}$ & $\mathrm{CL}$ & $\mathrm{CD}$ & FLM & 2 & 99 & $1(1)$ & $3(3)$ \\
\hline MO & 13-Jan-13 & 4 th & MR & $\mathrm{CD}$ & FLM & 5 & 99 & $1(1)$ & $2(2)$ \\
\hline $\mathrm{AW}$ & 27-Jul-13 & 4 th & $\mathrm{CL}$ & $\mathrm{CD}$ & FLM & 5 & 99 & $1(1)$ & $2(2)$ \\
\hline SP & 20 -Feb-14 & $1 \mathrm{st}$ & AN & $\mathrm{RG}$ & UFM & 4 & 99 & $1(1)$ & $2(2)$ \\
\hline
\end{tabular}

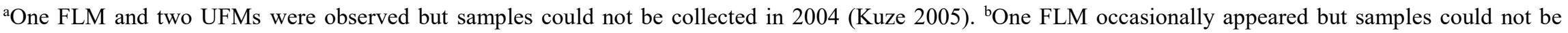
collected in 2009 . 
Table 3 Results of agonistic interactions among males

\begin{tabular}{cccccc}
\hline \multicolumn{5}{c}{ Looser } \\
\hline & $\mathrm{CD}$ & $\mathrm{MK}$ & $\mathrm{RG}$ & $\mathrm{TK}$ & Total \\
\hline $\mathrm{CD}(\mathrm{FLM})$ & - & 5 & 3 & 3 & 11 \\
$\mathrm{MK}(\mathrm{UFM})$ & & - & 4 & 2 & 6 \\
$\mathrm{RG}(\mathrm{UFM})$ & & & - & 5 & 5 \\
$\mathrm{TK}(\mathrm{UFM})$ & & & & - & 0 \\
\hline Total & 0 & 5 & 7 & 10 & 22 \\
\hline
\end{tabular}


Table 4 Number of male-male aggression by reproductive status of females in proximity

\begin{tabular}{ccc}
\hline \multirow{2}{*}{ Opponents } & \multicolumn{2}{c}{ Status of females in proximity } \\
\cline { 2 - 3 } & Reproductive parous & Nulliparous $^{\mathrm{a}}$ \\
\hline FLM-UFM (10) & 10 & 0 \\
UFM-UFM (12) & 10 & 2 \\
\hline
\end{tabular}

${ }^{\text {a }}$ No reproductive parous female was observed. 
Table 5 Number of successful copulations for each male and the partners' parity

\begin{tabular}{cccc}
\hline \multirow{2}{*}{ Male ID } & Focal hour & \multicolumn{2}{c}{ Female parity } \\
\cline { 3 - 4 } & & Parous & Nulliparous \\
\hline CD (FLM) & 43 & $2(1)$ & $0(0)$ \\
MK (UFM) & 150 & $4(3)$ & $7(4)$ \\
RG (UFM) & 204 & $14(11)$ & $13(9)$ \\
TK (UFM) & 41 & $3(1)$ & $1(1)$ \\
\hline
\end{tabular}

Number in parentheses indicates forced copulation. 
$1 \quad$ Table 6 Comparison with previous paternity studies

\begin{tabular}{|c|c|c|c|c|c|c|}
\hline \multirow{2}{*}{ Site } & \multirow{2}{*}{ Species } & \multirow{2}{*}{$\begin{array}{c}\text { Number of analyzed } \\
\text { offspring }^{\text {a }}\end{array}$} & \multicolumn{3}{|c|}{ Morph of father } & \multirow{2}{*}{ References } \\
\hline & & & FLM & UFM & Unknown $^{\mathrm{b}}$ & \\
\hline Ketambe & P. abelii & 10 & 4 & 6 & - & Utami et al. 2002 \\
\hline Kinabatangan & $\begin{array}{c}\text { P. pygmaeus } \\
\text { morio }\end{array}$ & 6 & 5 & 1 & - & Goossens et al. 2006 \\
\hline Tanjung Puting & $\begin{array}{c}\text { P. pygmaeus } \\
\text { wurmbii }\end{array}$ & 14 & 10 & 3 & 1 & Banes et al. 2015 \\
\hline Sepilok & $\begin{array}{c}\text { P. pygmaeus } \\
\text { morio }\end{array}$ & 6 & 4 & 1 & 1 & This study \\
\hline
\end{tabular}

2 a Criterion for paternity assignment is different among studies. ${ }^{b}$ Paternity could be assigned, but morph at the time of the offspring's conception was unknown. 